\title{
Leucine Rich Repeat Containing Protein
} 17

National Cancer Institute

\section{Source}

National Cancer Institute. Leucine Rich Repeat Containing Protein 17. NCI Thesaurus.

Code $C 38572$.

Leucine-rich repeat-containing protein 17 (441 aa, $52 \mathrm{kDa}$ ) is encoded by the human LRRC17 gene. This protein is involved in protein-protein interactions. 